\title{
Yield response of wheat cultivars to zinc application rates and methods
}

\author{
Yaser Arafat ${ }^{1}$, Muhammad Shafi ${ }^{1}$, Mushtaq Ahmad Khan ${ }^{2}$, Muhammad \\ Adnan $^{2 *}$, Abdul Basir ${ }^{2}$, Inayat-ur-Rahman ${ }^{2}$, Muhammad Arshad ${ }^{3}$, Abid \\ $\mathrm{Khan}^{4}$, Nouman Saleem ${ }^{2}$, Muhammad Romman ${ }^{5}$, Ziaur Rahman ${ }^{2}$ and \\ Jawad Ali Shah ${ }^{2}$
}

1. Department of Agronomy, The University of Agriculture, Peshawar-Pakistan

2. Department of Agriculture, University of Swabi, Anbar, Swabi-Pakistan

3. Mountain Agriculture, Research Center (MARC) Gilgit Baltistan-Pakistan

4. Agricultural Research Station, Buner, Khyber Pakhtunkhwa-Pakistan

5. Department of Botany, University of Malakand, Khyber Pakhtunkhwa -Pakistan

*Corresponding author's email: madnanses@gmail.com

Citation

Yaser Arafat, Muhammad Shafi, Mushtaq Ahmad Khan, Muhammad Adnan, Abdul Basir, Inayat-ur-Rahman, Muhammad Arshad, Abid Khan, Nouman Saleem, Muhammad Romman, Ziaur Rahman and Jawad Ali Shah. Yield response of Wheat cultivars to zinc application rates and methods. Pure and Applied Biology. Vol. 5, Issue 4, pp1260-1270. http://dx.doi.org/10.19045/bspab.2016.50151

\begin{tabular}{llll}
\hline \hline Received: 08/09/2016 & Revised: 09/11/2016 & Accepted: 14/11/2016 & Online First: 18/11/2016 \\
\hline
\end{tabular}

\section{Abstract}

To examine the effects of zinc and its application methods on yield and yield components of wheat varieties, a field experiment was conducted in randomized complete block design (RCBD) with split plot arrangement at the University of Agriculture, Peshawar during Rabi season 2013-14. There were 3 wheat varieties (Atta Habib, Siran-2010 and Janbaz) which were assigned to main plots. Four zinc levels $\left(0,3.5,7.00\right.$ and $10.50 \mathrm{~kg} \mathrm{ha}^{-1}$ ) and 3 application methods (Broad cast, side dressing and application with seed) which were allotted to sub plots making a total of 36 treatments per replication. The results revealed significantly higher number of days to anthesis (130), grain filling duration (31 days) and number of days to maturity (160) from variety Atta Habib while, maximum grains spike $^{-1}$ (49), thousand grain weight (43.36 g), grain yield (3911 $\left.\mathrm{kg} \mathrm{ha}^{-1}\right)$, biological yield (9173 $\left.\mathrm{kg} \mathrm{ha}^{-1}\right)$ and harvest index $(42.14 \%)$ were recorded for Siran-2010. Application of zinc (10.50 kg ha $\left.{ }^{1}\right)$ produced maximum plant height $(101 \mathrm{~cm})$, grains spike ${ }^{-1}(58)$, thousand grain weight $(51.26 \mathrm{~g})$ grain yield (4256 kg ha-1), biological yield (10521 kg ha-1) and harvest index (46.45\%). Similarly, significantly Higher plant height $(100 \mathrm{~cm})$, grains spike ${ }^{-1}(48)$, thousand grain weight $(41.11 \mathrm{~g})$, grain yield $\left(3859 \mathrm{~kg} \mathrm{ha}^{-1}\right)$, biological yield $\left(9457 \mathrm{~kg} \mathrm{ha}^{-1}\right)$ and harvest index $(41.72 \%)$ were obtained from side dressing method of zinc application. It may be concluded that Siran-2010 with application of $\mathrm{Zn}$ at the rate of $\left(10.50 \mathrm{~kg} \mathrm{ha}^{-1}\right)$ as side dressing produced relatively highest yield and yield components in wheat crop under existing agro-climatic conditions.

Keywords: Wheat; Varieties; Zinc; Application methods

\section{Introduction}

Wheat (Triticum aestivum L.) is considered as a chief source of food of all over the world. Under optimum management practices it has the capability to provide food and feed for rapidly growing humans and animals [1]. The total area occupied by wheat in Pakistan was 8.6 million hectares which produced 24.2 
million tones with average yield of $2796 \mathrm{~kg}$ ha $^{-1}$ while In Khyber Pakhtunkhwa area occupied by wheat was 0.72 million hectares producing 1.1 million tones with average yield of $1596 \mathrm{~kg} \mathrm{ha}^{-1}$ [2]. It has been investigated that grain yield production of wheat in Pakistan is less as compared to other countries like China, Russia and USA [3]. The problem of trace nutrients deficiency in both plants and soil are increasing day by day due to intensive farming and cultivation of high yielding genotypes with application of high doses of NPK fertilizer [4]. More than $48 \%$ area cultivated under cereal crops at world level has the problem of zinc deficiency [5].

Soils of Pakistan are generally alkaline in reaction and calcareous in nature. These types of soils usually contain low amount of available micronutrients, particularly zinc deficiency is widespread in cereals that are grown on calcareous soil $[6,7]$. The main soil factors affecting the availability of $\mathrm{Zn}$ to plants are low in total $\mathrm{Zn}$ contents, high $\mathrm{pH}$, high calcite and organic matter contents and high concentrations of $\mathrm{Na}, \mathrm{Ca}, \mathrm{Mg}$, bicarbonate and phosphate in the soil solution or in labile forms [8]. Wheat grown on calcareous soils and lowland rice on flooded soils are also highly prone to $\mathrm{Zn}$ deficiency. Zinc efficiency traits for sandy and clayey soils appear to be genetically different. Zinc efficient genotypes absorb more $\mathrm{Zn}$ from deficient soil; produce more dry matter and more grain yield [9]. Zinc deficiency in Pakistan soils has been recognized [10]. [11] Also reported the $\mathrm{Zn}$ deficiency in Khyber Pakhtunkhwa. Studies of [12] revealed the merits of $\mathrm{Zn}$ application to cereal crop. [13] Reported that zinc ranged between deficiency $\left(<0.5 \mathrm{mg} \mathrm{kg}^{-1}\right)$ and adequate limits $\left(>1.0 \mathrm{mg} \mathrm{kg}^{-1}\right)$ in Pakistan. Zinc is responsible for protein synthesis, metabolic process of plants, enhance $\mathrm{N}$ metabolism and un-adequate supply of $\mathrm{Zn}$ adversely affects protein synthesis [14]. Zinc deficiency negatively affects root growth, physiological functions and uptake of nutrients, which may lead to reduction in yield and yield components [15]. Zinc deficiency in plants adversely affects flowering and fruiting formation [16]. Trace nutrient including zinc reduce crop productivity may be due to their low contents in the soil. [17].

Application of trace nutrients including zinc may be applied through side dressing, foliar or broadcast enhanced yield and quality of wheat crop [18]. Placement of fertilizer within rows is more efficient and accessible to roots and gives best result compared to other methods of fertilization [19]. [20] Concluded that fertilization of nutrients including zinc and its application through different methods improved yield and yield components. Wheat crop growth, yield and yield attributes had positively affected with application of micro nutrients and their application methods [21]. The effects of different micro nutrients including zinc as well as its application methods had positively affected on crop growth, grains yield and yield parameters [22].

Keeping in view the importance of zinc and its application methods, the present experiment was conducted to investigate its impacts on yield and yield components of wheat varieties.

\section{Materials and methods}

Field experiment was conducted at Agricultural Research Farms of The University of Agriculture Peshawar-Pakistan during Rabi season 2013-14. Experimental site is located at $350 \mathrm{~m}$ above sea level. Mean annual rainfall ranged from $380-550 \mathrm{~mm}$. The experiment was conducted in randomized complete block design (RCBD) with split plot arrangement. Treatments were replicated three times. Wheat varieties (Siran-2010, Atta Habib and janbaz) were assigned to main plots While different levels of $\mathrm{Zn}(0,3.50$, 7.00 and $10.50 \mathrm{Zn} \mathrm{kg} \mathrm{ha}^{-1}$ ) and its application 
methods (Broadcast, Side dressed and application with seed ) was assigned to sub plots. A sub plot size of $4 \times 5 \mathrm{~m}^{2}$ was used. zinc sulphate $\left(\mathrm{ZnSO}_{4}\right)$ was used as a source of zinc $\left(\mathrm{Zn}^{+}\right)$. Recommended seed rate of $120 \mathrm{~kg} \mathrm{ha}^{-1}$ was used uniformly for all wheat varieties. A Basal dose of nitrogen $(120 \mathrm{~kg}$ $\mathrm{ha}^{-1}$ ) was applied in the form of urea in two splits $\left(1 / 2 \mathrm{~N}\right.$ before sowing and $1 / 2 \mathrm{~N}$ after $2^{\text {nd }}$ irrigation) to all plots. All other agronomic and cultural practices were carried out uniformly. Data collected included number of days to anthesis, grain filling duration, days to physiological maturity, plant height, grains spike $^{-1}, 1000$ grain weight, grain yield, biological yield and harvest index. Data were analyzed using the statistical package MSTAT-C [23] means were compared using least significant differences (LSD) test at $\mathrm{P} \leq 0.05$ upon significant F-test.

\section{Results and discussion Days to anthesis}

Data regarding days to anthesis of wheat as affected by wheat varieties, zinc levels and its application methods are presented in (Table 1). Analysis of the data showed that wheat varieties have significant effect ( $p \leq$ 0.05 ) on number of days to anthesis. Maximum number of days to anthesis (130) was recorded for wheat variety Atta Habib followed by Siran-2010 (126) while minimum number of days to anthesis (122) was recorded for Janbaz. Our results are similar with the finding of [24-26] reported that possible reason for variation in number of days to anthesis might be due to genetic variable characters of wheat varieties. The data further revealed that similar value for numbers of days to anthesis (126) was counted for all $\mathrm{Zn}$ levels i.e. (0, 3.50, 7.00 and $10.50 \mathrm{~kg} \mathrm{ha}^{-1}$ ) and its application methods (Broadcast, Side dressing and application with seed). Similar results are obtained by [27] Revealed that uniform growth and development depends upon the genetic makeup of varieties and environmental interaction.

\section{Grain fill duration}

Data regarding grain fill duration of wheat as affected by wheat varieties, zinc levels and its application methods are presented in (Table 1). Analysis of the data showed that wheat varieties had significantly $(\mathrm{p} \leq 0.05)$ affected grain fill duration of wheat crop. Maximum days (31) to grain filling duration were recorded for wheat variety Atta Habib followed by Siran-2010 (29 days) while minimum days (27) to grain fill duration was counted for Janbaz variety. [28, 29] reported that alteration in grain filling duration occurred due to genetic variability among wheat varieties. Equal days (29) to grain fill duration was recorded for all the applied different $\mathrm{Zn}$ levels (0, 3.50, 7.00 and $10.50 \mathrm{~kg} \mathrm{ha}^{-1}$ ). The equal day (29) to grain filling duration was recorded in case of all $\mathrm{Zn}$ application methods (Broadcast, Side dressing and application with seed). Our results are in conformity with [27] who reported that grains fill duration depends upon exposure of crop to sun light (photoperiod) and temperature which were experienced by all the plots uniformly.

\section{Days to physiological maturity}

Data regarding days to physiological maturity of wheat as affected by wheat varieties, zinc levels and its application method are presented in (Table 1). Analysis of the data revealed that varieties, zinc levels and its application methods showed significant effect $(p \leq 0.05)$ on number of days to physiological maturity of wheat. Highest number of days (160) to maturity was recorded for wheat variety Atta Habib followed by siran-2010 (157 days) which was at par with Janbaz with mean value of (157 days). Similar result is also obtained by $[24,25]$ concluded that heritable characteristics among wheat cultivars are the ultimate reason of variable number of days to physiological maturity. The data further 
revealed that maximum numbers of days (158) to physiological maturity was counted for zinc levels applied at the rate of 7.00 and $10.50 \mathrm{~kg} \mathrm{~h}^{-1}$ compared with minimum numbers of days (157) to physiological maturity with application of $3.50 \mathrm{Zn} \mathrm{kg} \mathrm{ha}{ }^{-1}$ and from control respectively. In case of application methods maximum number of days (158) to maturity was counted in $\mathrm{Zn}$ application as side dressing and application with seed. Minimum number of days (157) to physiological maturity was observed in broadcast method of $\mathrm{Zn}$ application. [27] Reported that rate of development in reproductive stage reflects the maturity of crops which mostly depend upon environmental factors.

Table 1. Days to anthesis, grain filling duration and days to maturity of wheat as affected by wheat varieties, Zinc levels and its application methods

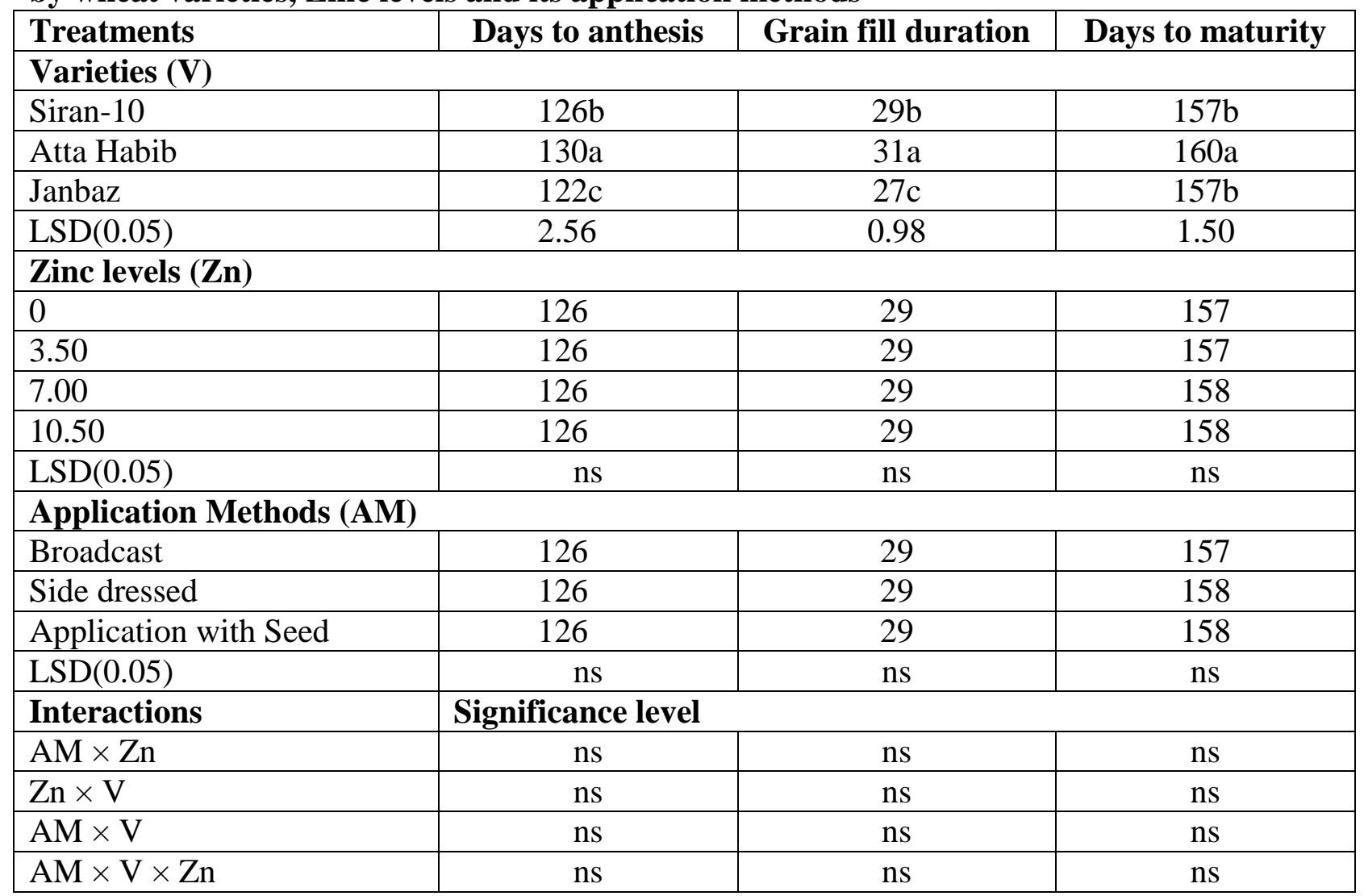

ns represents non-significant difference at $\mathrm{p} \leq 0.05$. Means with different letters in each column are significantly different at $\mathrm{p} \leq 0.05$ using LSD test

\section{Plant height (cm)}

Data regarding this plant character of wheat as affected by wheat varieties, zinc levels and its application methods is presented in Table 2. Statistical analysis of the data showed that varieties, different levels of zinc and its methods of application have significantly $(\mathrm{p} \leq 0.05)$ affected plant height of wheat crop. Taller plants $(100 \mathrm{~cm})$ were observed for variety Janbaz followed by Atta Habib (97cm) while shortest plants (96 $\mathrm{cm})$ for variety Siran-2010. Similar result is also obtained by [30-32] reported that genetic variability is the major cause for difference in plant height. Among different levels of zinc taller plants $(101 \mathrm{~cm})$ was produced by zinc level at the rate of $10.50 \mathrm{~kg}$ $\mathrm{ha}^{-1}$ statistically similar value for plant 
height $(99 \mathrm{~cm})$ was also obtained for zinc level at the rate of $7.00 \mathrm{~kg} \mathrm{ha}^{-1}$ followed by plant height $(97 \mathrm{~cm})$ for $3.50 \mathrm{Zn} \mathrm{kg} \mathrm{ha}{ }^{-1}$ while shorter plant height $(93 \mathrm{~cm})$ was calculated for control plot. [33, 34] concluded that application of zinc at the rate of $10 \mathrm{~kg} \mathrm{ha}^{-1}$ produced taller plants compared with control. Among $\mathrm{Zn}$ application methods maximum plant height of $(100 \mathrm{~cm})$ was calculated for side dressing method while statistically similar value of plant height $(96 \mathrm{~cm})$ was calculated for both $\mathrm{Zn}$ application methods broadcasting and application with seed. [35] Reported maximum plant height with application of $\mathrm{Zn}$ at $5.00 \mathrm{~kg} \mathrm{ha}^{-1}$ as side dressed application method.

Table 2. Plant height $(\mathrm{cm})$, grains spike-1 and 1000 grain weight (g) of wheat as affected by wheat varieties, $\mathrm{Zn}$ levels and its application methods

\begin{tabular}{|c|c|c|c|}
\hline Treatments & Plant height $(\mathrm{cm})$ & Grains spike $^{-1}$ & 1000 grain weight $(\mathrm{g})$ \\
\hline \multicolumn{4}{|l|}{ Varieties (V) } \\
\hline Siran-10 & $96 \mathrm{bc}$ & $49 \mathrm{a}$ & $43.36 \mathrm{a}$ \\
\hline Atta Habib & $97 \mathrm{~b}$ & $46 b$ & $39.00 \mathrm{~b}$ \\
\hline Janbaz & $100 \mathrm{a}$ & $45 b$ & $39.25 b$ \\
\hline $\operatorname{LSD}(0.05)$ & 2.94 & 1.34 & 1.64 \\
\hline \multicolumn{4}{|l|}{ Zinc levels (Zn) } \\
\hline 0 & $93 c$ & $33 \mathrm{~d}$ & $31.00 \mathrm{~d}$ \\
\hline 3.50 & $97 \mathrm{ab}$ & $45 c$ & $36.30 \mathrm{c}$ \\
\hline 7.00 & $99 a$ & $51 \mathrm{~b}$ & $43.59 \mathrm{~b}$ \\
\hline 10.50 & $101 \mathrm{a}$ & $58 \mathrm{a}$ & $51.26 \mathrm{a}$ \\
\hline $\operatorname{LSD}(0.05)$ & 2.98 & 1.69 & 1.19 \\
\hline \multicolumn{4}{|c|}{ Application Methods (AM) } \\
\hline Broadcast & $96 b$ & $46 b$ & $39.64 c$ \\
\hline Side dressed & $100 \mathrm{a}$ & $48 \mathrm{a}$ & $41.11 \mathrm{a}$ \\
\hline Application with Seed & $96 b$ & $45 b$ & $40.86 \mathrm{a}$ \\
\hline $\operatorname{LSD}(0.05)$ & 2.58 & 1.46 & 1.03 \\
\hline Interactions & \multicolumn{3}{|l|}{ Significance level } \\
\hline $\mathrm{AM} \times \mathrm{Zn}$ & ns & ns & ns \\
\hline $\mathrm{Zn} \times \mathrm{V}$ & ns & $\mathrm{ns}$ & $\mathrm{s}$ \\
\hline $\mathrm{AM} \times \mathrm{V}$ & $\mathrm{ns}$ & ns & $\mathrm{ns}$ \\
\hline $\mathrm{AM} \times \mathrm{V} \times \mathrm{Zn}$ & ns & ns & ns \\
\hline
\end{tabular}

ns represent non-significant difference at $\mathrm{p} \leq 0.05$. Means with different letters in each column are significantly different at $\mathrm{p} \leq 0.05$ using LSD test

\section{Grain spike ${ }^{-1}$}

Data regarding grain spike $^{-1}$ of wheat as affected by wheat varieties, zinc levels and its application methods is presented in Table 2. Statistical analysis of the data showed significant effect $(\mathrm{p} \leq 0.05)$ of wheat varieties, Zinc and its application methods on grains spike ${ }^{-1}$. Among wheat varieties Siran-2010 produced more numbers of grains spike ${ }^{-1}$ (49) while statistically similar grain spike ${ }^{-1}$ was counted for varieties Atta Habib (46) and Janbaz (45). Our results are in agreement with findings of $[36,37]$ who reported that variation in numbers of grains spike $^{-1}$ occurred due to variable genetic potential of varieties for the trait. Among various $\mathrm{Zn}$ levels more number of grain spike $^{-1}$ (58) was counted for Zn applied at 
the rate of $10.50 \mathrm{~kg} \mathrm{ha}^{-1}$ followed by grain spike $^{-1}(51,45)$ at the rate of 7.00 and 3.50 $\mathrm{Zn} \mathrm{kg} \mathrm{ha-1}$ respectively. While control plot give minimum number of grain spike ${ }^{-1}$ (33). Our results are similar with the findings of $[38,34,39]$ who revealed that zinc is responsible for improved flowering induction, fruit formation and finally enhanced number of grains. Data regarding $\mathrm{Zn}$ application methods showed that $\mathrm{Zn}$ applied as a side dressing counted for maximum grains spike $^{-1}$ (48) followed by broadcast method (46) which was statistically at par to $\mathrm{Zn}$ applied with seed method (45). Our findings are fruitful with finding of [19] who reported that application of zinc as side dressed method performed better in term of grains spike ${ }^{1}$.

\section{Thousand grain weight (g)}

Data regarding thousand grain weight of wheat as affected by varieties, zinc levels and its application methods are presented in Table 2. Statistical analysis of the data showed that significant $(\mathrm{p} \leq 0.05)$ influence of varieties, $\mathrm{Zn}$ levels and its application methods was observed for 1000 grains weight of wheat crop. In case of wheat varieties Siran-2010 produced highest 1000 grains weight (43.36 g) followed by Atta Habib (39.00 g) which was statistically at par with Janbaz (39.25 g). Our results are in agreement with the finding of $[36,30,37]$ who reported that variation in 1000 grains weight (g) occurred due to variable water and nutrients use efficiency of varieties. In case of various $\mathrm{Zn}$ levels, $\mathrm{Zn}$ applied at the rate of $10.50 \mathrm{Zn} \mathrm{kg} \mathrm{ha}{ }^{-1}$ resulted in maximum thousand grain weight $(51.26 \mathrm{~g})$ followed by $\mathrm{Zn}$ level at the rate of $7.00 \mathrm{~kg}$ $\mathrm{ha}^{-1}$ and $3.50 \mathrm{~kg} \mathrm{ha}^{-1}$ with 1000 grains weight of (43.59 and $36.30 \mathrm{~g})$ respectively while minimum thousand grain weight (30.00 g) was recorded from control plot. Our result is in agreement with the finding of [40-42] who also find out that zinc has improved water and nutrients availability to roots and consequently increased 1000 grains weight $(\mathrm{g})$. $\mathrm{Zn}$ application as a ide dressing resulted in higher 1000 grains weight $(41.11 \mathrm{~g})$ which was statistically similar with $\mathrm{Zn}$ application with seed method with mean value of (40.86 g) and lowest thousand grain weight $(39.64 \mathrm{~g})$ was recorded in broadcast method of $\mathrm{Zn}$ application. Similar result was observed by [35] who obtained highest thousand grain weight in side dressing application of zinc. Grain yield (kg ha-1)

Data regarding grain yield of wheat as affected by wheat varieties, zinc levels and its application methods are presented in Table 3. Statistical analysis of the data revealed that wheat Varieties, zinc levels and its application methods have significantly affected $(\mathrm{p} \leq 0.05)$ grain yield of wheat crop. In case of Wheat varieties Siran-2010 produced highest grains yield (3911) which was at par with variety Atta Habib (3778kg ha ${ }^{-1}$ ) While minimum grains yield (3581) was produced by Janbaz. Our result is similar with the finding of $[36,43]$ who reported that genetic variability among varieties might be responsible for variable grain yield. In case of zinc levels, Zn applied at the rate of $10.50 \mathrm{~kg} \mathrm{ha}^{-1}$ produced maximum grain yield (4256 $\mathrm{kg} \mathrm{ha}^{-1}$ ) followed by $\mathrm{Zn}$ used at the rate of 7.00 and $3.50 \mathrm{~kg} \mathrm{ha}^{-1}$ with grains yield of (3886 and $\left.3664 \mathrm{~kg} \mathrm{ha}^{-1}\right)$. Similar result is also obtained by $[44,40,34,45]$ who concluded that application of adequate amount of zinc has improved water and nutrients availability, enhanced cell physiology which may lead to improved grains yield. Among zinc application methods side dressing produced maximum grains yield $\left(3859 \mathrm{~kg} \mathrm{ha}{ }^{-1}\right)$ followed by application of $\mathrm{Zn}$ with seed (3716 kg ha $\mathrm{kg}^{-1}$ ) while minimum grain yield $\left(3695 \mathrm{~kg} \mathrm{ha}^{-1}\right.$ ) obtained in case of broadcast method of $\mathrm{Zn}$ application. Similar result is also obtained by [35] who reported that side dressing application of zinc improved grain 
yield compared with other methods of $\mathrm{Zn}$ application.

Table 3. Grain yield $\left(\mathrm{kg} \mathrm{ha}^{-1}\right)$, biological yield $\left(\mathrm{kg} \mathrm{ha}^{-1}\right)$, and harvest index (\%) of wheat as affected by wheat varieties, Zinc levels and its application methods

\begin{tabular}{|c|c|c|c|}
\hline Treatments & Grain yield(kg ha-1) & By $\left(\mathrm{kg} \mathrm{ha}^{-1}\right)$ & Harvest index (\%) \\
\hline \multicolumn{4}{|l|}{ Varieties (V) } \\
\hline Siran-10 & $3911 a$ & $9173 a$ & $42.14 \mathrm{a}$ \\
\hline Atta Habib & $3778 \mathrm{a}$ & $8845 b$ & $41.03 \mathrm{~b}$ \\
\hline Jan-baz & $3581 b$ & $8820 \mathrm{ab}$ & $39.42 c$ \\
\hline $\operatorname{LSD}(0.05)$ & 169.59 & 226.16 & 1.07 \\
\hline \multicolumn{4}{|l|}{ Zinc (Zn) } \\
\hline 0 & $3221 d$ & $6898 d$ & $34.89 \mathrm{~d}$ \\
\hline 3.50 & $3664 \mathrm{c}$ & $8924 c$ & $38.56 \mathrm{c}$ \\
\hline 7.00 & $3886 b$ & $9440 b$ & $43.56 b$ \\
\hline 10.50 & $4256 a$ & $10521 \mathrm{a}$ & $46.45 \mathrm{a}$ \\
\hline $\operatorname{LSD}(0.05)$ & 131.24 & 229.91 & 0.95 \\
\hline \multicolumn{4}{|l|}{ Application Methods (AM) } \\
\hline Broadcast & $3695 c$ & $8693 b$ & $39.95 b$ \\
\hline Side dressed & $3859 a$ & $9457 \mathrm{a}$ & $41.72 \mathrm{a}$ \\
\hline Application with Seed & $3716 b$ & $8688 \mathrm{ab}$ & $40.92 \mathrm{a}$ \\
\hline $\operatorname{LSD}(0.05)$ & 113.66 & 199.11 & 0.83 \\
\hline Interactions & \multicolumn{3}{|l|}{ Significance level } \\
\hline $\mathrm{AM} \times \mathrm{Zn}$ & ns & ns & ns \\
\hline $\mathrm{Zn} \times \mathrm{V}$ & ns & ns & ns \\
\hline $\mathrm{AM} \times \mathrm{V}$ & ns & ns & ns \\
\hline $\mathrm{AM} \times \mathrm{V} \times \mathrm{Zn}$ & ns & ns & ns \\
\hline
\end{tabular}

ns represent the significant and non-significant difference at $p \leq 0.05$. Means with different letters in each column are significantly different at $\mathrm{p} \leq 0.05$ using LSD test

\section{Biological yield ( $\left.\mathrm{kg} \mathrm{ha}^{-1}\right)$}

Data regarding biological yield of wheat as affected by wheat varieties, zinc levels and its application methods are presented in Table 3. Statistical analysis of the data showed that wheat varieties, Zn levels and its application methods have significantly affected $(\mathrm{p} \leq 0.05)$ biological yield of wheat. Among varieties Siran-2010 produced highest biological yield (9173 $\left.\mathrm{kg} \mathrm{ha}^{-1}\right)$ followed by Atta Habib (8845 $\mathrm{kg} \mathrm{ha}^{-1}$ ) which was at par with Janbaz $\left(8820 \mathrm{~kg} \mathrm{ha}^{-1}\right)$. Similar result was also obtained by $[46,37]$ who reported that difference in biological yield of wheat varieties might be due to their variable plant height characteristics and growth habit. In case of zinc Levels, $\mathrm{Zn}$ applied at the rate of $10.50 \mathrm{~kg} \mathrm{ha}^{-1}$ produced maximum biological yield (10521 kg ha-1) followed by application of $\mathrm{Zn}$ at the rate of 7.00 and $3.50 \mathrm{~kg} \mathrm{ha}^{-1}$ produce biological yield of (9440 and $8924 \mathrm{~kg} \mathrm{ha}^{-1}$ ) while control plot give lower biological yield (6898 $\mathrm{kg} \mathrm{ha}^{-1}$ ) Similar result was also obtained by [40]. Who find out that application of zinc in adequate amount has improved water and nutrients availability and photosynthetic activities which may lead to improved biological yield. Application of zinc as a side dressed method produced maximum biological yield (9457 $\mathrm{kg} \mathrm{ha}^{-1}$ ) followed by broadcast (8693 $\mathrm{kg} \mathrm{ha}^{-}$ ${ }^{1}$ ) which was at par with application of $\mathrm{Zn}$ with seed $\left(8688 \mathrm{~kg} \mathrm{ha}^{-1}\right)$. same result was 
also obtained by [22] concluded that application of $\mathrm{Zn}$ as side dressed application method has improved mobility of $\mathrm{Zn}$ to roots and enhanced plants growth that resulted highest biological yield.

\section{Harvest index (\%)}

Data regarding harvest index of wheat as affected by wheat varieties, zinc levels and its application methods are presented in Table 3. Statistical analysis of the data showed that wheat varieties, Zn levels and its application methods have significantly affected ( $\mathrm{p} \leq 0.05$ ) harvest index of wheat. Among wheat varieties maximum harvest index $(42.14 \%)$ was calculated for Siran2010 followed by Atta Habib (41.03\%) while minimum harvest index was calculated for Janbaz (39.42\%). Our results are similar with finding of $[47,37]$ reported that difference in harvest index might be due to genetic variability of varieties. Among zinc levels, Application of $\mathrm{Zn}$ at the rate of $10.50 \mathrm{~kg} \mathrm{ha}{ }^{-1}$ produced highest harvest index $(46.45 \%)$ followed by harvest index (43.56 and $38.56 \%)$ at levels of (7.00 and $3.50 \mathrm{~kg} \mathrm{Zn} \mathrm{ha}^{-1}$ ) respectively. Lower harvest index $(34.89 \%)$ was calculated for control plot. Similar result is also obtained by [48] Revealed that application of zinc has positively changed harvest index of wheat. Among application methods, $\mathrm{Zn}$ applied as a side dressing results in highest harvest index $(41.72 \%)$ which was statistically at par with application method with seed with mean value of $(40.92 \%)$ and lowest harvest index $(39.95 \%)$ was recorded in broadcast method of $\mathrm{Zn}$ application. Our results are similar with finding of [19] Reported that application of $\mathrm{Zn}$ as side dressing has led to maximum harvest index.

\section{Conclusions and recommendations}

Highest grain yield of (3911 kg ha ${ }^{-1}$ ) was produced by Siran-2010 followed by Atta Habib (3778 $\mathrm{kg} \mathrm{h}^{-1}$ ) as compared with lowest grain yield $\left(3581 \mathrm{~kg} \mathrm{ha}^{-1}\right.$ ) produced by Janbaz. Application of zinc at the rate of
$10.5 \mathrm{~kg} \mathrm{ha}^{-1}$ produced maximum grain yield $\left(4256 \mathrm{~kg} \mathrm{~h}^{-1}\right)$ followed by zinc levels of (7.00 and $3.50 \mathrm{Kg} \mathrm{ha}^{-1}$ ) with grain yield of (3886 and $3664 \mathrm{~kg} \mathrm{ha}^{-1}$ ) respectively while control produced lower grain yield of (3221 $\left.\mathrm{kg} \mathrm{ha}{ }^{-1}\right)$. Among application methods of Zinc, side dressing method ranked $1^{\text {st }}$ with production of grain yield (3859 $\mathrm{kg} \mathrm{ha}^{-1}$ ) followed by application of $\mathrm{Zn}$ with seed method (3221 kg ha-1) while broadcast method of $\mathrm{Zn}$ application ranked $3^{\text {rd }}$ with production of $\left(3695 \mathrm{~kg} \mathrm{ha}^{-1}\right)$. It is suggested that, cultivation of Siran-2010 with application of $10.50 \mathrm{~kg} \mathrm{Zn} \mathrm{ha}{ }^{-1}$ as side dressing is relatively best combination for obtaining good yield and yield components of wheat crop under existing agro-climatic conditions.

\section{Authors' contributions}

Designed the experiment: M Shafi \& M Adnan, Performed the experiments: MA Khan, Y Arafat \& A Basir, Analyzed the data: IU Rahman \& M Arshad, Contributed the materials: N Saleem \& A Khan, Wrote the paper: JA Shah, M Romman \& Z Rahman.

\section{Acknowledgement}

The authors are thankful to the University of Agriculture Peshawar for conducting this experiment on their resources.

\section{References}

1. Khalil SK, khan F, Rehman A, Muhammad F, Ullah A, Khan AZ, Wahab S, Akhtar S, Zubair M, Khalil IH, Shah MK \& Khan H (2011). Dual purpose wheat for forage and grain yield in response to cutting, seed rate and nitrogen. Pakistan Journal of Botany 43(2): 937-947.

2. MNFSR (2013). Ministry of National Food Security and Research. Islamabad-Pakistan

3. Khan MA, Hussain I \& Baloch MS (2000). Wheat yield potential current status and future strategies. Pak J Biol Sci 3(1): 82-86. 
4. Cakmak I (2002). Plant nutrition research: Priorities to meet human needs for food in sustainable ways. Plant and Soil 247: 3-24

5. Graham RD \& Welch RM (1996). Breeding for staple food crops with high micronutrient density: Agriculture strategies for micronutrients (Working Paper No.3). Washington, D.C: IFPRI.

6. Maqsood MA, Ullah R, Kanwal S, Aziz $\mathrm{T} \&$ Ashraf M (2009). Evaluation of Zn distribution among grain and straw of twelve indigenous wheat (Triticum aestivum L.) genotypes. Pak J Bot 41(1): 225-231.

7. Rashid A \& Ryan J (2008). Micronutrient contents to crop production in the Near East. Significance and Management Strategies. In: Micronutrient Deficiencies in Global Crop Production. (Ed.): B. J. Alloway. Springer Science + Business Media B.V Pp 149.

8. Ghulam A, Gul H, Muhammad AA, Muhammad A \& Zafar A (2010). Response of wheat to different doses of $\mathrm{ZnSO} 4$ under thal desert environment. Pak J Bot 42(6): 40794085.

9. Graham RD, Ascherand JS \& Hynes SC (1992). Selecting zinc efficient cereal genotypes for soils of low zinc status. Plant and Soil 146(1-2): 241-250.

10. Hadi A, Taran SA, Azeem A, Saeed Z \& Aslam M (1997). Wheat response to zinc application in rice growing area of Baluchistan. Pakistan Journal of Soil Science 13: 25-27.

11. Khattak JK \& Parveen S (1986). Micro nutrient status of Pakistan soils and their role in crop production. Bull. Soil Sci. No. 1. Department of soil sci. NWFP Agric. Uni. Peshawar Pakistan.

12. Marwat KB, Arif $M$ \& Khan MA (2007). Effect of tillage and $\mathrm{Zn}$ application methods on weeds and yield of maize. Pak J Bot 39(5): 1583-1591.

13. Abbas ST, Sarfraz M, Mehdi SM, Hassan G \& Rehman OU (2007). Trace element accumulation in soil and rice plants irrigated with the contaminated water. Soil Tillage Research 94(2): 503-509.

14. Mengel K, Kirkby A, Kosegarten H \& Appel T (2001). Principles of plant nutrition, 5th edition. Dordrecht, the Netherlands: Kluwer Academic Publishers.

15. Fageria NK (2004). Influence of dry matter and length of roots on growth of five field crops at varying soil zinc and copper levels. J Plant Nutri 27: 15171523.

16. Epstein E \& Bloom AJ (2005). Mineral nutrition of plants: Principles and perspectives, 5th Ed. Sunderland, Mass: Sinauer Associates, Inc.

17. Sharma JC \& SK Chaudhary (2007). Vertical distribution of micronutrient cat ions in relation to soil characteristics in lower shivaliks of Solan district in north-west himalayas. J Ind Soc Soil Sci 55(1): 40-44.

18. Malakouti MJ (2008). The effect of micronutrients in ensuring efficient use of macro-nutrients. Turk J Agric For 32(3): 215-220.

19. Nadim MA, Awan IU, Baloch MS, Khan EA, Naveed K \& Khan MA (2012). Response of wheat (Triticum aestivum $L$.) to different micro-nutrients and their application methods. J Animal \& Plant Sci 22(1): 113-11.

20. Soleimani R (2006). The effects of integrated application of micronutrient on wheat in low organic carbon conditions of alkaline soils of western Iran. Proc. 18th World Congress of Soil Sci., July 9-15, Philadelphia, USA. 
21. Khan H, Hassan ZU \& Maitlo AA (2006). Yield and micronutrients content of bread wheat (Triticum aestivum L.) under a multi-nutrient fertilizer (Hal-Tonic). Intl J Agric Biol 8(3): 366-370.

22. Nadim MA, Awan IU, Baloch MS, Khan N \& Naveed K (2013). Micronutrient use efficiency in wheat as affected by different application methods. Pak $J$ Bot 45(3): 887-892.

23. Steel RGD \& Torrie JH (1980). Analysis of Covariance. In: Principles and Procedures of Statistics. A Biometrical Approach. $2^{\text {nd }}$ Ed., McGraw-Hill New York. 401-437.

24. Shahzad K, Bakht J, Shah WA, Shafi M \& Jabeen (2002). Yield and yield components of various varieties as influenced by sowing dates. Asian $J$ Plant Sci 1(5): 522-525.

25. Munsif F, Arif M, Jan MT, Ali K \& Khan MJ (2015). Influence of sowing dates on phenological development and yield of dual purpose wheat cultivars. Pakistan Journal of Botany 47(1): 83-88.

26. Rehman AI, Ahmad NH, Hussain M, Khan MA, Farooq J \& Ali MA (2009). Screening wheat germplasm for heat tolerance at terminal growth stage. Plant Omics J 2(1): 9-19.

27. Nawab, Khalid, Shah P, Arif M, Ullah A, khan MA, Mateen A, Rab A, Munsif F \& Ali K (2011). Effect of cropping patterns, farm yard manure, $\mathrm{K}$ and zinc of wheat growth and grain yield. Sarhad J Agric 27(3): 371-375.

28. Khan MI, Khan AJ, Khatak GSS \& Subhan F (2014). Genetic effects in controlling grain filling duration in wheat croses. J Animal \& Plant Sci 24(3): 803-813.

29. Uddin R, Subhani GM \& Ahmad N (2010). Effect of temperature on development and grain formation in spring wheat. Pakistan Journal Botany 42(2): 899-906.

30. Hussain S, Hussain MI \& Saleem M (2001). Growth and yield response of three wheat varieties to different seeding densities. Int J Agri Biol 03 (2): 228- 229 .

31. Rashid MH, Samanta SC, Biswas P, Mannan MA \& Zaman AKM (2004). Performance of thirty wheat genotypes under late sown conditions in southern region of Bangladesh. Asian J Plant Sci 3(3): 286-289.

32. Al-Otayk SM (2010). Performance of yield and stability of wheat genotypes under high stress environments of the central region of Saudi Arabia. JKAU: Met. Env and Arid Land Agric Sci 21(1): 81-92.

33. Ranjbar GA \& Babmaniar MA (2007). Effects of soil, foliar application of zinc fertilizer on yield and growth characteristics of bread wheat (Triticum aestivum L.) cultivars. Asian J Plant Sci 6: 1000-1005.

34. Khan R, Gurmani AR, Khan MS \& Gurmani AH (2009). Residual, direct and cumulative effect of zinc application on wheat and rice yield under rice- wheat system. Soil and Environ 28: 24-28.

35. Ali MA, Tariq NH, Ahmed N, Abid M \& Rahim A (2013). Response of wheat to soil applied boron and zinc fertilizers under irrigated conditions. Pak J Agri. Sci 29(2): 114-125.

36. Tahir M, Tanveer A, Ali A, Ashraf M \& Wassaya A (2008). Growth and yield response of wheat varieties to different potassium levels. Pak J Life soc Sci 6(2): 92-95.

37. Shakileh MS, Yasari E, Foroutan A \& Reza H (2012). Investigation of effects of bread wheat (Triticum aestivumL.) cultivars cultivation in mountainous 
area of Mazandaran of northern Iran. Int J Agric Crop Sci 4(13): 868-872.

38. Zeidan MS, Mohamed MF \& Hamouda HA (2010). Effect of foliar fertilization of $\mathrm{Fe}, \mathrm{Mn}$ and $\mathrm{Zn}$ on wheat yield and quality in low sandy soils fertility. World J Agri Sci 6 (6): 696-699.

39. Genc Y, Donald GK \& Graham RD (2006). Contribution of different mechanisms to zinc efficiency in bread wheat during early vegetative stage. J Plant and Soil 281: 353-367.

40. Khan MA, Fuller MP\& Baluch FS (2008). Effect of soil applied zinc sulphate on wheat (Triticum aestivum L.) grown on a calcareous soil in Pakistan. Cereal Research Communications. 36(4): 571-582.

41. Monjezi F, Vazin F \& Elouei $\mathrm{MH}$ (2013). Effects of iron and zinc spray on yield and yield components of wheat (Triticum aestivum L.) in drought stress. Cercetari Agronomic in Moldova XLVI, No. 1 (153).

42. Jiang lina Zhang D, Song F, Zhang $X$, Shao Y \& Li C (2013). Effects of zinc on growth and physiological characters of flag leaf and grains of winter wheat after anthesis. Advance J Food Sci and Tech 5(5): 571-577.
43. Iqtidar H, Ayyaz KM \& Ahmad KE (2006). Bread wheat varieties as influenced by different nitrogen levels. J Zhejiang Univ Sci Biol 7(1): 70-78.

44. Goswami VK (2007). Response of wheat (Triticum aestivum L.) to nitrogen and zincapplication. Ann Agric Res New Series 28 (1): 90-91.

45. Hafeez B, Khanif YM \& Saleem M (2013). Role of zinc in plant nutrition. American J Exptl Agri 3(2): 374-391.

46. Hussain N, Khan M A \& Farid R (2005). Effect of varying levels of phosphorous and zinc on growth and yield of wheat (Triticum aestivum L.) cultivars. Agric Sci J Pak 2(1): 1- 4.

47. Moghadam MJ, Abad HHS, Mohamadi GN, Motahar SYS \& Siadat SA (2012). The effect of zinc, boron and copper foliar application, on yield and yield components in wheat. Sch

Res Libr Ann Biol Res 3(8): 38753884.

48. Keram KS, Sharma \& Sawarkar BL (2012). Impact of zinc application on yield, quality, nutrients uptake and soil fertility in a medium deep black soil (vertisol). Int J Sci Envi Tech 5: 563 571. 